\title{
English Language Influence on Russian Commercial Names
}

\author{
Svetlana Pitina \\ Chelyabinsk State University, Chelyabinsk, Russian Federation
}

\begin{abstract}
The paper is an attempt of sociolinguistic and cultural analysis of the cognitive mechanisms in commercial names nomination of various urban organizations. One thousand Chelyabinsk commercial names influenced by English language are studied. It is shown that commercial names make up an open lexical system depending on social and cultural changes, in which English influence on nomination is an evident and growing tendency. Language fashion is realized in commercial nomination via the influence of English as a global language on the Russian word-building system. Pragmatic function of commercial names, transformations of lexical meanings in the process of borrowing from English into Russian, and creativity in local word-building are discussed.
\end{abstract}

Keywords: nomination, loan words, commercial names, assimilation, transformation

\section{Introduction}

Recent dramatic transformations in the Russian Federation after perestroika at the end of the last century influenced all spheres of life. Language as communication means cannot stand apart from the process and answers to new social tendencies on all its levels. Language contacts are extremely significant in language development. Vocabulary changes happen quicker in comparison to changes on phonological and grammatical levels, introduced, spread, and noticed by language users as they reflect numerous new social, economical, and cultural phenomena.

A new for the Russian Federation type of economic relations resulted in the appearance of many privately or state owned big, average, and small firms, shops, studios, and clubs which had and still have to be officially registered and named. The nomination process of such commercial organizations is necessary but difficult to regulate and standardize, hopefully a sociolinguistic study of the phenomenon will lead to a number of recommendations for businessmen and city administration on how to avoid or minimize mistakes in commercial names creation.

\section{Theoretical Frame}

Urban names study in Russian linguistics is socially oriented, targeted at revealing new tendencies of social life: transition from group to individual mentality, dynamism of communication, creative language usage, variation and almost unrestricted freedom. Urban names form a system of artificial proper names possessing universal and unique features. Urban names can be stable (place names) and open to changes (micro-place names: names of streets, buildings; commercial names...) (Pitina, 2013; Pitina, 2014).

Commercial names or ergonyms (from Greek 'ergon - work and 'onyma - name) are studied in Russian linguistics as a special type of proper names denoting a business group of people, such as union, organization, 
institution, corporation, society, office, and club (Podolskaja, 1988, p. 151). The first attempt to classify commercial names was undertaken by Superanskaja. Ergonyms form two opposite groups: (1) real, indicating where the company is located or what it produces and (2) symbolic, containing implicit indication of its activity. Abbreviations of commercial names can be referred to both types (Superanskaja, 1973, p. 197).

Shchetinin states that commercial names perform an aesthetic function as they are chosen to create a festive atmosphere for consumers (Shchetinin, 1968).

Shimkevich supposes that ergonyms can be pragmatic, with a clearly expressed speech influence on an addressee and without such influence (Shimkevich, 2002). He divides pragmatic ergonyms into informative, providing additional information about an organization and associative, creating positive associations. However, all ergonyms are informative for city dwellers and in most cases for city guests. It seems that all ergonyms are pragmatic and positively motivated because they are created for marketing reasons to promote the result of a certain commercial group activity. Such names are secondary motivated formations, formed from proper or common names or set phrases.

A detailed description of commercial names classifications, possible ways of translating, thematic groups of ergonyms are given by Konovalova and Lupacheva (Konovalova \& Lupacheva, 2013).

Samsonova approaches ergonyms of foreign origin as a system in the communicative space of a city from the aspects of nomination, language creativity, and foreign influence. Any word or phrase with a motivated foreign element in commercial names is understood by her as ergonym (Samsonova, 2012, p. 248). It is a wide approach to foreign words study.

Lozovoj and Nazvanova prove that extra-linguistic factors dominate in the naming mechanisms of ergonyms (Lozovoj \& Nazvanova, 2013, p. 25).

Commercial names are in general studied on the local material that allows analyzing universal and specific tendencies of their development and functioning. They are divided into native and borrowed, the latter being completely, partially, or not assimilated words, barbarisms. Completely assimilated foreign words in commercial names are not analyzed in this paper because they are already a part of Russian vocabulary.

There is a growing interest in ergonyms analysis in Russian linguistics because a number of problems are still open for study. Among such problems is the role of English language on Russian commercial names.

\section{Method}

This study is a sociolinguistic and cultural approach to analyzing Chelyabinsk commercial names that are influenced by the English language. The target of the integral analysis is to gather information about: (1) the structural and semantic peculiarities of commercial names; (2) the major social spheres conditioning the formation of commercial names influenced by English language; and (3) the problems of commercial names perception by Russians.

\section{Data Collection}

Data collection consisted in the content analysis of about 1,000 commercial names influenced by English language found in the lists of 5,000 Chelyabinsk commercial organizations. ${ }^{1}$ Chelyabinsk commercial names are grouped into 27 spheres of activities. Only three types of commercial names with the largest number of

\footnotetext{
${ }^{1}$ See www.topfirm.ru; www.chelyab.ru; www.morefirm.ru|Chelyabinsk|, etc.
} 
names with English language influence are chosen for analysis. They include education, tourism, and shopping. Original orthography is preserved in the examples. Famous English brands are not studied.

\section{Results}

The first ergonyms influenced by English language appeared in Chelyabinsk in the 90s of the last century as a result of the new tendencies in political, economical and cultural policy in Russia after the end of the Cold War. Private initiatives in business were approved by the country and city administrations; contacts with foreign partners were established; business trips abroad became possible for more people. English language knowledge became an important factor in career building. It conquered a large territory of the city communicational space and firmly established itself in the quickly growing system of commercial names, adapting to the new local space, sometimes blending with Russian language, sometimes preserving and sometimes losing the original meaning and spelling.

\section{Commercial Names Influenced by English Language in Educational Sphere}

There was only one high school with teaching some subjects in English in Chelyabinsk in the last half of the 20th century. At present, the English language is not only a part of syllabus of all state educational establishments, but of 127 privately owned schools and teaching centers. Their commercial names are represented by English words and phrases. 20\% of names contain the word English: Planet English, World of English, Royal English, English Club, English Accent, Study English, My English, English Geek, composite neologisms Englishland, Englishup, even a slogan with a difficult and ambiguous beginning FasTrackEnglish...

Components planet and world are typical of Russian ergonyms and of the general tendency to hyperbolize in the Russian naming tradition, however small a language school or center can be.

A few educational ergonyms contain British place names: Stratford School, Oxford School, Cambridge School, Oxbridge, Liverpool, UK Club, British Club... Such names reveal a stereotype that it is more effective to teach beginners the British variant of English and then to pass to other variants. British precedent names are found in Camelot, Big Ben, and Robin Good Consulting.

Many names concretize the type of educational establishment or its pragmatic function: Sun School, Royal Academy, Language Academy, Language Study, Study English, Class, Studyland, Study on. However, some ergonyms are too general: World, Friends, Pioneer, transliterated Globus.

Several educational ergonyms can be attractive to future students because they are good result-oriented: $I Q$, Intelligence, Smart, Progress. Names I like, Enjoy imply that language study is not difficult. Ergonyms Duckling, Look Book, Diplomat, Hello do not indicate the type and target group of educational commercial names. Diplomat and Lingvostars, Lingvomaster are rather pretentious names for small language centers.

$I Q 007$ is an ironically sounding local blend (it unites $I Q$, a well known abbreviation, and the end of the precedent name), demonstrating creativity of the local nomination process. However, the whole net of the English language learning centers $D I Y$ is a wrongly used abbreviation. Native Language is another misleading name for a language center recruiting students whose native tongue is Russian.

Commercial names of English language schools and centers in Chelyabinsk are borrowed from English vocabulary and are registered in their original form. 


\section{Commercial Names of Travel Agencies Influenced by English Language}

There are hundreds of large and small travel agencies in Chelyabinsk, about $40 \%$ of whose names are in English or represent the mixture of English and Russian words or transliterations from English into Russian.

The keywords in Chelyabinsk tourist agencies names are travel and tour. They are combined with concretizing nouns, adjectives, pronouns, and adverbs used as first components of a phrase: Star travel, Dream travel, Exotic travel, Easy travel, Lucky travel, Golden travel, Fiesta travel, Millennium travel, Coral travel, All travels, Your travel, Olimp travel (with i), Vita travel, Sky travel, Love travel, More travel, Owl tour, Lucky tour, Afrotravel, ParkCity travel, Patriot tour, Paradise tour, Fresh tour, Favorite tour, Family tour, Royal tour, Exotic tour, Discount tour, VIP tour... The first part of such phrases is added to the nouns travel and tour to attract the tourists with some knowledge of English to exotic, new, often cheap to go and much promising places. Words travel and tour are sometimes combined in tourist ergonyms with proper names to indicate the owner of the agency or a precedent name: Olga travel, Victoria travel, Marina-club, Avalon. Travel logic, Travel dream, Travel point and Tour agency CHEmodan (with an ambiguous transliterated into Latin alphabet last component denoting either a suitcase or a blend formed from Chelyabinsk plus the Russian version of the noun suitcase) are the examples in which words travel and tour occupy the initial position. Room travel sounds ironical. Like travel and So travel are ambiguously sounding names (either particle to is omitted in the first example or some comparison with the missing beginning is implied; in the second example the meaning is also difficult to understand).

Other generalizing words in tourist ergonyms include world, club, holiday, group, agency, way, land, resort: Ural-resort, Universal group, Aviator club, Exotic world, Lotus way, composite neologism Studyland formed on the analogy with England, Tour agency, Sunny holiday. Only one agency name registered in English language organizes tours around Ural.

Touristar is an original blend formed from the nouns tourist and star. Russian and English words can be mixed in Матрешка (Russian doll) travel, МноGО туров (the first word is a Russian-English blend formed from many in Russian and go), Pycb-travel (from the poetic synonym to Russia and travel). Many tourist ergonyms are transliterations from English into Russian: Даймонд тур, Бэст тур, Бриз-трэвел, Дримтур, Алпин-драйв, Ривертур.

Tourist agencies names without direct indication to the sphere of activity are also numerous: World express, Discovery, Prosper link, Sea magic, Blue Sky...

Commercial names of Chelyabinsk tourist agencies influenced by English language are structurally and semantically different. They are not often fresh, metaphorical and can be found in many other cities. Creativity of tourist ergonyms influenced by English language is realized in blends.

\section{Commercial Names of Shops Influenced by English Language}

The third group of ergonyms is the most numerous due to the variety and number of shops, different ways of English language influence, more expressed advertizing function, and many effective and rather misleading ergonyms.

One word names prevail in this group of ergonyms: Casual, Outfit, Reserved, Shape, Shift, Stylish, Guess, Twist, Savage, People, Easy, Beauty, House, Solid, Extra, Collection, Your, Outlet, Funny, Stylish. They are simple commercial names of Chelyabinsk shops formed by nouns, adjectives, pronouns which can be simple 
and compound: Shopland, blend Enerjeans, partially transliterated Shopomir. Some of them are registered with mistakes: Brend and its derivative Brender, Befree.

Ergonyms-phrases are often more original in graphic and sound forms, more structurally different.

The main word-building models include:

(1) noun plus noun: Fit Zone;

(2) two nouns joined by a coordinative conjunction: Business and Casual;

(3) two nouns connected by a preposition: Work of art;

(4) adjective plus noun: New art;

(5) numeral plus noun: First Light;

(6) possessive pronoun plus noun: My club.

They include rhymed names, word repetition, alliteration: Yes Dress No Stress, Door and Floor, Shop and Shop, Pur Pur, Clipsa Calipso (with the mixed naming of the Russian word spelled in Latin alphabet and the precedent name), Тор ten, Тор типе, Тренды-Бренды (alliteration is the result of transliteration from English). Shops with clearly motivated names To be bride, Love Story, Miss White, Be loved sell wedding dresses. Puns are also characteristic of Chelyabinsk shop names in English language: Wool Street, Pull and bear, E-motion...

The noun city is often found in shop names often without a clear indication to the type of a shop: City style, City smile, City brand, City call, Such city, In city, but there is also a concrete shop name Candles city, transliterated Леди Сити. If the proper name Chelyabinsk is found in shop commercial names, the shop type is usually indicated: Chelmusic.ru, Chel.bike.ru, Chelauto.ru, transliterated Chelshina.ru, kuzov-chel, partially transliterated composite nouns Chelnиво, СhеІткани, Chel-вагончик.

Frequently used adjectives in two-component shop names include the adjective new: New star, New season, New time, New baby, color names: Red bomb, Red cristal, Red cristall, Redsolution, Red Cup.

Shop names can indicate the type of a shop or the level of prices: Baby \& Shop, Baby-boss, Baby Chic, Baby Boots, Babytime, Babymama, Babycool, Born, Baby 74, Kids 74.ru, Sporthouse 74, Magic doors, Fix Price. Many variants of spelling can never be found in English dictionaries.

Proper names and precedent names are frequently found in shop ergonyms: Elena Furs, Anita-lady, Olivenko group, Gulliver, Lolita74.ru, Camelot, Everest, Stradivarius, Nyorker with wrong transliteration. There are several Russian non-transliterated Russian proper names in shop ergonyms: St Petersburg, Russia.

Shop names can denote positive emotions; Positive, Compliment, Respect and the same in meaning, transliterated into Russian, ergonym Респекm, Euphoria, Pride, Freshface (the registered spelling is preserved), Savage, Emotion production, SOS... Adjectives magic, modern, fresh, great, clean, new, personal pronoun my acquire positive connotations and are used to attract customers: Magic doors, Modern house, Fresh-Design, Great Nature, Clean power, New season, My Desires.

The shortened variant of the adjective ecological is also meant to be customer attractive in shop names: Ecolife, Ecobooth. The same pragmatic function is true of the adjective professional: Pro-mpomyap, Proabmo. Optic shops Ргозрение, Рговижение both mean proper vision. They are puns resulting from the mixture of English and Russian letters in one word.

High quality of goods made in Europe always attracted and still attract Russians. There appeared a number of word combinations with European to indicate the best possible quality of service or goods: blends евроремонт (repair like in Europe most often done by workers from Asia), евро-окна (windows made and 
installed by local workers), евро-дизайн (no designers from Europe are invited)... The names of shops also follow this pseudo-European fashion: Eurofurs, EвpoStyle.

Nouns mister and lady are used in local ergonyms to indicate the highest quality goods: Mister Lux, Mr. doors, Mr. cap, Lady +, Sexy Lady, Леди Сити, Леди прима (transliteration examples). Nouns fashion and style perform the same pragmatic function in shop names: Fashion box, Fashion rose, Serious style, Jeans Style.

Commercial names of shops can sometimes be equivalent to short self-motivating sentences: I'm style, I like, imperative Hit Life.

Ergonyms may become ambiguous as a result of transliteration from Russian into English. Desert is not an area of land with no water and almost no vegetation, but dessert, something sweet to eat at the end of a meal!

Chelyabinsk commercial names of shops are made of English words and phrases, parts of English words added to Russian words that can be transliterated into English or written in Cyrillic, misspelled English words. Compounding and blending are most frequently found ways of word-building in such ergonyms.

\section{Conclusion}

Local commercial names reflect the general tendencies of language development. These globalization tendencies combine the influence of English on nomination processes, on the one hand (globalization), and strong local traditions of nomination (localization), on the other. The influence of English language is realized in three ways: (1) English words, phrases and sentences are used to name Russian commercial organizations; (2) English and Russian words are blended in one commercial name; and (3) transliteration, complete and partial, from English into Russian.

It is possible to make a conclusion that educational centers and travel firms are named by people with a good command of English. There is a more creative and less strict approach to the nomination of shops.

\section{References}

Konovalova, I. A., \& Lupacheva, T. A. (2013). Translation problems of Primorsky Krai ergonyms in electronic media. In Proceedings of Institute of Oriental Studies. Vladivostok: Publ. FEFU.

Lozovoj, A. Yu., \& Nazvanova, I. A. (2013). On nomination problem. Modern Ergonym Peculiarities. In Proceedings of Southern Federal University. Rostov on Don: Publ. SFU.

Pitina, S. A. (2013). Peculiarities of urban names globalization. In VI International Lazarev Conference: Traditional Culture Images at the Beginning of XXI century. Chelyabinsk: Publ. Chelyabinsk State Academy of Culture.

Pitina, S. A. (2013). Language and cultural analysis of urban names (on Las Vegas casino names example). Bulletin of Chelyabinsk State University, 4(295). Chelyabinsk: Publ. CSU.

Podolskaja, N. V. (1988). Dictionary of Russian onomastic terminology. Moscow: Publ. Science.

Samsonova, E. S. (2012). Notion of foreign origin ergonyms system in the urban communicative space. Siberian Journal of Science, 4(5).

Shchetinin, L. M. (1968). Names and appellations. Rostov n/D: Publ. Rostov University.

Shimkevich, N. V. (2002). Russian commercial ergonyms: Pragmatic and linguocultural aspects (Ph.D. thesis on Philology, Ekaterinburg).

Superanskaja, A. V. (1973). General theory of proper name. Moscow: Publ. Science. 